\title{
HR Practices and Organizational Innovation: The Mediating Role of Knowledge Management Effectiveness
}

\author{
Muhammad Farooq, Irfan Ullah, Raja Mahzhar Hameed \\ Iqra University, Islamabad, Pakistan \\ chfarooq111@gmail.com, irfanullahtarar1979@gmail.com,rajamazharhameed@yahoo.com
}

\begin{abstract}
Organizational innovation has been recognized as an important instrument for organizations to compete in the competitive environment. Pakistan telecom sector strive to transform their business model from labour-intensive to knowledge-intensive, which intend to thrust themselves in higher value added activities such as, developing new products, processes, and services, to continual sustain the competitiveness. One of the means to increase the organizational innovation is through effective human resource management practices and effective knowledge management. This study examined the direct association between human resource management practices (performance appraisal, career management, training, reward system, recruitment and employee recognition) and organizational innovation. Moreover, it also observed the mediating role of knowledge management effectiveness on the direct relationship. Data was collected from a sample of 290 personnel of telecom sector of Pakistan. The regression results showed that human resource management practices generally had a positive impact on organizational innovation. Particularly, the results signify that training and employee recognition were positively related to three dimensions of organizational innovation. Performance appraisal also established to have a positive impact on administrative innovation. Additionally, this study also demonstrates that training, performance appraisal, and employee recognition were positively associated to knowledge management effectiveness.
\end{abstract}

Keywords: Human resource management practices, organizational innovation, knowledge management effectiveness

\section{Introduction}

Theoretical Background: Organizations adopt new technology for attaining the desired goals, which normally referred as a source of firm's innovation and creation. This improvement has urged several firms to learn the latest techniques, innovative ideas, research based outcomes and reliable innovative solutions. These activities refine existing products, methods, approaches, and structures for future survival. Because of these efforts, the essential drivers influence the firm's capabilities to create the competitive environment in services or products. The main strategically target of organization is to live in that specific business market. Effective and reliable human resource practices (HRP) create the specific job attitudes amongst the employees towards the firm's innovation (Tan \& Nasurdin, 2010). HR Practices enhance awareness, employee inspiration, cooperation and obligation amongst the employees (Harter, Schmidt \& Hayes, 2002). Finally, a continual and regular effort helps in business development and creates the better environment for the business activities. Therefore, various researchers such as Morrow and McElroy (2003) discussed that a weak connection and relation between HRM practices and firm activities badly affects the organizational goals.

The research results of human resource management show that creativity and innovation is big and strong function, which increases the values, maintain competitive business gains and help the employees to adopt quickly varying atmosphere (Zoghi, Mohr \& Meyer, 2010). Navarro et al. (2010), and AL-Hakim and Hassan (2011) stated that innovational process and plans always depends on employees creative skills, knowledge, proficiency and dedication are the main instruments for value creation procedure. Those organizations are receiving the good and better results, which adopted the innovational and creative environment in the organization. These organizations succeeded to promoting the capable employees for better organizational performance. 
Primary purpose of human resource practices is that firms set the direction of skills, behavior of individual employee and attitudes for doing their assignments to achieve firms already selected goals. When an innovational process starts in the organization, it is helpful in enhancing the capable, creative and skillful employees for producing the valuable products and services. Therefore, this expertise helped the organizational human capital for achieving the desired goals. These practices help and motivate the employees to do their duties and assignments effectively. Firms identify and sort out the set of strategic HR practices, which examine the HR practices effect on the employees for achieving the organizational goals through innovational activities (Ullah \& Yasmin, 2013). According to Weisberg (2006), conducting and implementing the strategic HR practices increase the innovational activities, because strategic HR practices support these activities for achieving the desired goals of the organization. However, knowledge and awareness cannot be easily transferred in to any individual employee in the firm, although human capital is the key asset of an organization. When an organization has enough access to the knowledge, expertise of existing employees and skills, so that firm manage and use the knowledge management instruments for attaining the organizational goals through innovational activities. Effectively managing the knowledge is a technique that maintains a balance between the organizational expertise and individual minds (Tan \& Nasurdin, 2010).

Knowledge management helps the organization for achieving their goals that already selected by the management of the organization. For increasing the knowledge and new technology, services providing firms are using the knowledge management systems and practices with efficiently for maintaining the competitive environment (Yazhou \& Jian, 2013). The translation of knowledge management is that first recognize the challenge and manage the activities through applying the informational instrument. Knowledge management implies a series of policies and guidelines means creating, diffusing and institutionalizing of knowledge to achieve the firm's objectives and goals. Although information technologydriven perspectives have traditionally dominated the field of knowledge management through use of knowledge and employee recognition, which enhance the employee performance and 'people perspective' concept in the organizations (Feng-Chuan Liu et al., 2012).

Problem Identification: Research shows that developed countries are going fast in organizational innovational activities like USA and European Union, but developing countries are slow to adopting the innovational activities like Pakistan (Ismail, 2005; Wan Jusoh, 2000; Yazhou \& Jian, 2013). Main impact of innovation is to create the competitive environment in business market. Numerous scholars explain and find out the related processes of innovative activities like employee characteristic, behavior and motivation towards the innovation activities in the organization (Mesmer-Magnus \& Dechurch, 2009). Researchers like Miller and Friesen (1982), Damanpour, Szabat and Evan (1989) have analyzed the relationship between innovation and environmental factors, and they found a strong association with each other. Organizational innovation and organizational structure have also relationship with each other. Researcher's point of view, there is a research gap; further reliable research can enhance the innovative activities through better use of HR practices in the organization (Tan \& Nasurdin, 2010). Dobni (2006) stated that better use of knowledge enhances the firm's innovational activities through sharing of existing knowledge and information. In the study of Ling \& Nasurdin (2010), it was exclaimed that knowledge management effectiveness is the missing link in the relationship of HR practices and organizational innovation. This research gap motivates the scholars for further study in this particular area. The purpose of this study is to intricate the best use of knowledge management role as a mediation and the link among human resource management practices (employee performance appraisal, employee career management, employee training, reward system of organization, employee recruitment and employee recognition) and firm innovation (products innovation, processes innovation and administrative innovation) within the Pakistani telecom industry.

Problem Statement: Previous research show that HRM practices have a dominant effect on firm's innovational activities, policies, procedures and processes. When appropriately manage and rearrange, then these practices support knowledge and innovational activities in the organization. It helps the organization to achieve the goals and creating the competitive advantage in the business economy. The purpose of this study is to investigate the impact of HRM practices on organizational innovation and mediating role of knowledge management. 
Objective of the Study: The main purpose of the study is

- Analyzing and investigating the role of HRM practices for achieving the organizational goals and improvement of work effectiveness.

- Analyzing and exploring the role of HRM practices for finding and removing existing obstacles for employees and providing them professional guidance.

- Signify the link among HRM practices, organizational innovation and knowledge management effectiveness in business.

Rationale of the Study: Researchers believe that effective knowledge is a basic mode of wealth creation and prosperity. Knowledge is one of the most significant strength for the success of an organization (Alshekaili \& Boerhannoeddin, 2011; Wang, Noe \& Wang, 2014). Knowledge management (KM) has progressively become an interesting issue for the development of companies. The researchers believe that knowledge management is the management of organizational knowledge. This school of thought pays more consideration on file management, knowledge base, data warehouse, data mining, concept and emphasis on the establishment of organizational knowledge management system (Amidon, 2006; Yazhou \& Jian, 2013).

Wang and Noe (2010) stated that knowledge is effectively planed and prepared data, which supports for sustainable competitive business advantage in business markets. Main objective of the knowledge management is effective use of knowledge and facilitate the access of knowledge among all employees of the organization. Therefore, the focus is to transfer the knowledge as an asset of organization in to fresh and existing employees. Taking the actions and initiatives are helpful for achieving the main objectives of the firm. Based on these reasons, it is essential to examine the influencing factors, which motivate the employees and knowledge sharing process inside the organization. Important thing is that "scope of knowledge inside the organizational departments through sharing the innovative and professional knowledge management." Previous research results showed that there is a positive relation between knowledge sharing and firm innovation, so this relationship increased firm productivity and improved employee performance. The main advantages of knowledge is to influence the management that they promote and encourage the knowledge sharing activities through different ways like money, employee training, rewards and flexible environment through knowledge management projects. Mostly knowledge management projects failed due to weak interest of organizational management (Wang \& Noe, 2010).

Research Contribution: The proposed model is evaluating the impact of HRM Practices on organizational innovation and mediating role of knowledge management. The design of this research is to fill the research gap by introducing new constructs with positive results. The key variables are HR practices, knowledge management effectiveness and organizational innovation (Shipton et al., 2005; Chen \& Huang, 2009; Tan \& Nasurdin, 2011). This study focused on new construct employee recognition that is going to be studied in the umbrella of human resource management practices. The reason behind is that as the past studies have focused on few or different constructs with their impact on organizational innovation. This study investigates each variable with number of items from previous adapted scales. The findings of this research are definitely valuable for the HR practitioners to understand the knowledge management towards the organizational innovation.

\section{Literature Review and Research Model}

Organizational Innovation: Now a day, organizational innovative activities are necessary for development of the organization with positive behavior and effective use of knowledge management (Damanpour \& Gopalakrishnan, 2001). The ways and techniques of firm's innovation are tremendously multifaceted. It can be analyze in main two parts: one is breadth of innovation, which contains rules, structures, managerial procedures, existing products and services. Another thing is deepness of innovation and creativity that is more important, defining the inspiration level of the employees, outcome on long run productivity and services by (Chuang, 2005). Tan and Nasurdin (2010) stated that literature showed, there are main two types of firm's innovation, one is advance technological innovations and second is administrational innovations. The technological innovation is secondary dimensions that are products innovations and 
processes innovations, although administrational innovations significantly differ from the second innovation. Research results explain that firm innovation categorized into main three scopes, which are products innovations, processes innovations and administrative innovations. According to Tan and Nasurdin (2010) and Chuang (2005) have distributed the firm innovation and creativity into the main three types first products innovations, second is processes innovations and third is administrational innovations. According to Cooper (1998), products innovations, processes innovations and administrative innovations are the main precursors for engineering organizations and these increase worth of the organization. These activities resolve problems, enhance value creation and make the reasonable business advantages. For increasing industrial organizational growth, it depends on products innovations, processes innovations and administrative innovations. Therefore, the organizational innovation is operating for multi categorized containing of these main three kinds of firms innovation: product innovation, process innovation and administrative innovation.

Human Resource Practices: Shipton et al. (2005) stated that HR practices is a set of practices that uses by the firm for management of HR practices through enabling the progressive capabilities like creative multifaceted public relationship, creative knowledge and collection of firm knowledge for maintaining competitiveness advantage. An earlier research shown, that a set of HR practices mostly associated on unique or good practicable method for enhancing the firm innovation. Analyses of the different researchers explain the main six general practices, which are regularly relates with firm innovation. Those general practices are employee performance appraisal, management of employee future growth, compensation system, advance training and selection \& employee recognition (Jiménez-Jiménez \& Sanz-Valle, 2005). In contradiction of these weaknesses, the author included the HR practices relating to particular practices, formal rules and beliefs. These practices have special shape to appeal, improve, inspire and retain workers that certify the actual running and survival of the firm. Therefore, these HR practices can be general or superlative experienced methodology (Delery \& Doty, 1996); strategic HR practices method (Huselid, 1995); contingency methodology (Wright \& McMahan, 1992) and configuration methodology (Schuler, 1989).

Knowledge Management Effectiveness: When an organization maintains the learning environment and provides the facilities to employees for this purpose, then organization maintains the effective knowledge management system. This effective knowledge enhances the innovational activities, which are helpful for achieving the organizational goals. The employee learning behavior enhances the storage of knowledge that offered to the firm for accomplishment of innovational activities. According to Darroch and McNaughton (2002) stated that when a firm explains capability in management of knowledge, so it explains deliberation as possessing the vision of knowledge management. Effective knowledge management means that a set of organized actions to increase the storage of knowledge for the organizational development and innovation from inside and outside the organization. Darroch and McNaughton (2002) stated that efforts to enhancing the knowledge management involve the formation of knowledge based tasks, flow of the knowledge management inside the firm and utilization of knowledge in a real and efficient way for the long term benefits of the firm. Gold, Malhotra and Segars (2001) argued that KM is a procedural viewpoint, which helps in achieving the organizational goals. Knowledge management is considered as a procedure to improve creative knowledge and apply for attaining firms' innovation and development. Those firms that are efficiently managing their knowledge in their creative and talent employees are becoming more innovative and creative.

Human Resource Practices and Organizational Innovation: According to Paauwe and Boselie (2005) argued that human resources point of view a theory, which is a popular theory in all theories which applied in the studies of human resource. That connects human resource management and progress that is ability, motivation and opportunity. RBV stated that human resource is an essential resource of the all resources of organization. HR supports the organization to attaining the business competitive advantage, which leads to seniors for durable procedure? Therefore, employees will achieve organizational goals effectively, when employees are inspire and motivated (Paauwe \& Boselie, 2005). HR practices perform the significant role in inspiring employees to show satisfactory in the shape of sets that supports and applicable the firms to maintain the competitive approach for the survival of an organization. Innovative organizational deal 
through HR practices as the firms approach to inspire teamwork, increase firm philosophy and create client relationships through sharing and authorization the authorities in subordinates (Wang \& Noe, 2010). According to Gupta and Singhal (1993) stated that innovational activities help the firm to make new products and provide unique services for the customers and consumers.

\section{Figurer 1: Theoretical Model}

Independent Variable

Dependent Variable

Organizational Innovation

\section{HRM Practices}

Mediating Variable

- Performance Appraisal

- Career Management

- Advance Training To Employee

- Reward System

- Employee Recruitment

- Recognition of Employee Performance

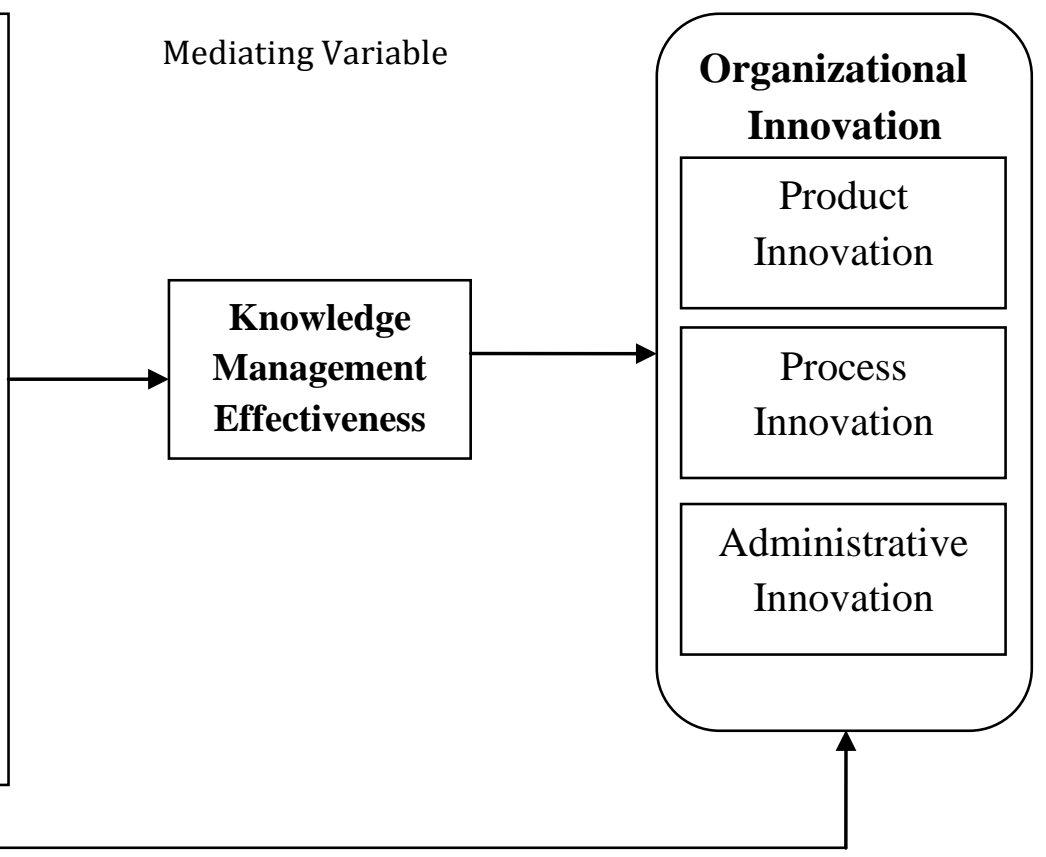

According to Chen and Huang (2009) stated that an organization produce and announce a new product, new procedure, new administrational practices, organization requires advance innovative employees, those are adjustable with the task, risk taker and forbearing of hesitation and uncertainty. Therefore, these employees are greatly important and necessary in IT industries. These employees participate for achieving the organizational objectives through market awareness, products and procedural innovation. Numerous researchers explained that supportive HR practices of organization helpful for employee inspiration and encourage to employees for becoming the innovative and creative (Jiménez-Jiménez \& Sanz-Valle, 2005; Laursen \& Foss, 2003; Shipton et al., 2005; Ullah \&Yasmin, 2013). HR practices positively connected to organizational advance innovational process and system. For example, performance appraisal enhances commitment of employee and satisfies before employees have providing opportunities to debate about their job performance. Based on the literature review, study model is in Figure 1.

Therefore, the result will guide the organization to complete and create innovational actions and activities for achieving the goals of the organization. Career growing management guides workers to achieve their career growth aims and purposes. When an employee feels satisfaction with career growth opportunities, then it causes to encouraging and inspiring to act for advance innovational actions (Delery \& Doty, 1996; Ullah et al., 2012). Advance training of employees improve the knowledge, skillfulness and capability of employees to accomplish efficiently assigned innovative targets. According to Schuler, (1989) stated that advance training of employee supports employee for desirable advance knowledge with their skills and capabilities. When employee involve in advance innovational activities, so production procedures and human resource practices works efficiently for achieving the organizational goals.

Compensation system offers economic return; career growth opportunities and employee recognition 
purpose are to encourage employees to participate in risky opportunities and introduce new products/services and create advance concepts for the organizational competitive advantage (Guptal \& Singhal, 1993). Compensation system inspires employee's motivation, so it enhances employee contribution through creation of advance innovational concepts and leading to the firm advance innovation. Schuler (1989) argued that recruitment and selection contains engaging, attaining suitable and capable applicants through outside sources. Recruitment and selection system fairly involved to appropriate between the candidate and organizational values. When organization involve the recruitment procedure for hiring of extra ordinary employees for creational activities and maintain the innovational environment for getting the advantages of organization from the market, so this is the suitable way for organization to earns a lot profit . After studying the literature, thus key hypotheses are raising and mention below:

$\boldsymbol{H}_{1}$ : The levels of HR practices (employee performance appraisal, employee career growth management opportunities, advance employee training, employee compensation system and recruitment / selection and employee recognition) are positively related to the firm advance innovations (products innovations, processes innovations and administrational innovations).

$H_{1 a}:$ The levels of HR practices (employee performance appraisal, employee career growth management opportunities, advance employee training, employee compensation system, and recruitment / selection and employee recognition) are positively related to the products innovation.

$H_{1 b}$ : The levels of HR practices (employee performance appraisal, employee career growth management opportunities, advance employee training, employee compensation system and recruitment / selection and employee recognition) are positively related to the processes innovation.

$H_{1 c}$ : The levels of HR practices (employee performance appraisal, employee career growth management opportunities, advance employee training, employee compensation system and recruitment / selection and employee recognition) are positively related to the administrative innovation.

Knowledge Management as a Mediator: Previous literature and researchers like Hislop (2003), Morrow and McElroy (2003) and Moynihan et al., (2001) discovered the gap among HRM practices and organizational outcomes that is the organizational innovation. Knowledge management is known as the significant act for attaining, increasing and supporting rational resources in firms. It is one mediating instrument from successive organizational innovation, that is knowledge management and it mediates among firm's factors and firms outcomes. According to Alshekaili \& Boerhannoeddin, 2011), the affiliation among human resources and advance innovational growth through mediating effect of knowledge management. Tung (2004) showed the knowledge management as a mediator and knowledge management mediates the link among firm beliefs, organizational value and organizational structure. It is necessary according to research point of view to observe the indirect association among firm advance innovation and HR practices through knowledge management. Fundamental the association among HR practices and firm advance innovation that were misplace in earlier researches. Therefore, HR practices concluded a decisionmaking procedure that permits the organization to manage efficiently to development of organizational advance innovation, so it is main hub of data traveling unit in the organization (Shipton et al., 2005; Usman et al., 2012). Thus, assumed and hypothesized that:

$\mathrm{H}_{2}: \quad$ Knowledge management mediates the association among $H R$ practices (performance appraisal, career growth management, advance employee training, compensation system, recruitment and employee recognition) and firm advance innovation (products innovation, processes innovation and administrative innovation).

$\boldsymbol{H}_{2 a}$ : Knowledge management mediates the association among $H R$ practices (performance appraisal, career growth management, advance employee training, compensation system, recruitment and employee recognition) and products innovation.

$\boldsymbol{H}_{2 b}$ : Knowledge management mediates the association among HR practices (performance appraisal, career growth management, advance employee training, compensation system, recruitment and employee recognition) and processes innovation.

$\boldsymbol{H}_{2 c}$ : Knowledge management mediates the association among HR practices (performance appraisal, career growth management, advance employee training, compensation system, recruitment and employee recognition) and administrative innovation. 


\section{Methodology}

This research tends to assess the influence of human resource practices on knowledge management effectiveness and organizational innovation. This study depends on the hypothetical deductive method. Based on this approach, it divided the research design in the systematic parts and research design begins from enough literature review. Finding the research gap to be targeted for this specific research area. According to Sekaran (2006), this approach starts from conceptual background and modeling, enough literature review, developing hypothesis and generating authentic results from the research. Point out the valid and reliable reasons that why this research is significant to fulfill the specific literature gap from research point of view. So on these reasons preparation of problem statement and preparation of research questions based on problem statement, which developed by the researcher. Selecting and preparation of objectives of the research helps the researchers for taking and collecting the right answers of research questions and conducting the study and developing of conceptual framework is the next step. There are main two parts of data collection (1) instrument development, population, sampling, reliability and validity (2) analysis of identify the unit and conduct fieldwork. For empirical testing, the questionnaire method adopted and selected from the selected sample (collected data).

Instrument: The questionnaires were distributed among different managers in Islamabad and Rawalpindi and it had two parts. The first part included the demographics and second part included the different independent variables, which are related with each other and also mediating variables with the dependent variables. All of these questions were measured on the five-point Likert scale ranging from $1=$ Strongly Disagree to 5 = Strongly Agree.

Table 1: Summary of Measuring Instrument

\begin{tabular}{lll}
\hline Construct & No of Items & Reference \\
\hline Performance Appraisal & 6 & Singh et al. (2004) \\
Career Management & 3 & \\
Advance Training to Employees & 5 & Rogg et al. (2001) \\
Reward System & 6 & Singh et al. (2004) \\
Employee Recruitment & 4 & Singh et al. (2004) \\
Recognition of Employee Performance & 4 & \\
Knowledge Management & 16 & Wang et al. (2008) \\
Product Innovation & 3 & Jimenez-Jimenez and Sanz-Valle (2008) \\
Process Innovation & 4 & (Popadiuk and Choo, 2006) \\
Administration Innovation & 4 & Jimenez-Jimenez and Sanz-Valle (2008) \\
\hline
\end{tabular}

\section{Variable Measurement}

Human Resource Management Practices: Table 1 shows the instrument summary. According to table, 28 items that included career management (three items), performance appraisal (six items), reward system (six items), recruitment (four items), training (five items) and employee recognition (four items) measured the HRM practices. The items of reward system, performance appraisal and employee recruitment were taken from Singh et al (2004). The scale was used to measure career management and employee recognition was measured by a questionnaire instrument that had 4 items. Completing required tasks and employee also received feedback from managers regarding his or her progress on job and this credit goes to employee and supervisor through appreciation.

Knowledge Management Effectiveness (KME): Effective Knowledge management was comprised of 16 items. The items were taken from previous study of Wang et al. (2008). The response format was based on a five-point Likert scale ranging from (one) 'strongly disagree' to (five) 'strongly agree'. 
Organizational Innovation: Organizational advance innovation was measured using 10 items that included processes innovations ( 3 items), products innovations ( 3 items) and administrational innovations (4 items). Products innovations and administrational innovations items were taken from Jimenez-Jimenez and Sanz-Valle (2008). Technical innovations items were taken from Popadiuk and Choo (2006).

Population and Sampling: A quantitative research methodology was used and for finalizing the research instruments, the descriptive and causal research used to conduct the survey. In Pakistan, the Telecom Sector is growing fastly for many years. The telecom industry of Pakistan includes cellular operators, long distance international (LDI) operators, fixed local loop (FLL) operators and wireless local loop (WLL) operators. The famous organizations included in this sector like (Zong, Telenor, PTCL, Mobilink, Warid Telecom, Ufone, which are located in twin cities of Pakistan; Islamabad and Rawalpindi. The target people for this study were managerial level employees of telecom sector. A sample from Telecom Sector includes the companies like Mobilink, PTCL, Ufone, Warid, Telenor and Zong. Three of them PTCL, Ufone and Mobilink are national and other three (Telenor, Warid and Zong) are multinational. Why choosing these managerial level employees? Because they have experience, knowledge and better understanding regarding various aspects of HR practices, knowledge management and organizational innovation. Moreover, these organizations follow the same regulations, products of all the organizations are almost same and cultures are identical. Population of telecom sector is very large so convenient sampling technique was used for collection of data. 400 questionnaires were distributed among managerial level employees who were working in telecom sectors of Pakistan.

Assessing Reliability: For measuring, the internal consistencies of the statements, the Cronbach's alpha are used which covers the particular factor and it measures reliability of statements to the specific construct. Therefore, in this study researcher used Cronbach's alpha to measure the reliability of statements. Cronbach's Alpha coefficient is a value for reliability having values from zero to one. Its higher value indicates greater reliability. Generally, scholars use 0.6 as a minimum level (Jolibert \& Jourdan, 2006).

Table 2: Reliability of Measurement Instrument

\begin{tabular}{lll}
\hline Research Concept & No. of Items & Chronbach alpha \\
\hline Performance Appraisal & 6 & 0.77 \\
Career Management & 3 & 0.80 \\
Employee Training & 5 & 0.72 \\
Reward System & 6 & 0.82 \\
Employee Recruitment & 4 & 0.67 \\
Employee Recognition & 4 & 0.84 \\
Knowledge Management Effectiveness & 16 & 0.67 \\
Product Innovation & 3 & 0.73 \\
Process Innovation & 3 & 0.76 \\
Administration Innovation & 4 & 0.87 \\
\hline
\end{tabular}

Table 2 demonstrates the results of reliability analysis for every construct. The results show that Chronbach's alpha varied from 0.67 to 0.87 . It was distinguished that all of the alpha values were above than 0.6 . These data expose that reliability of study constructs is good.

Confirmatory Factor Analysis: Confirmatory factor analysis was practiced, as an analysis of variables validity to expose that hypothetical intimating of a variable was empirically acquisitioned by its indicators. According to Hair et al. (2006), implementing this method researcher was able to confirm about how good all the manifest variables of the same construct relate with each other. Table 3 shows the estimates of the variables of the study, which were significant and considered well for further analysis. 
Table 3: Estimates of Constructs of the Study

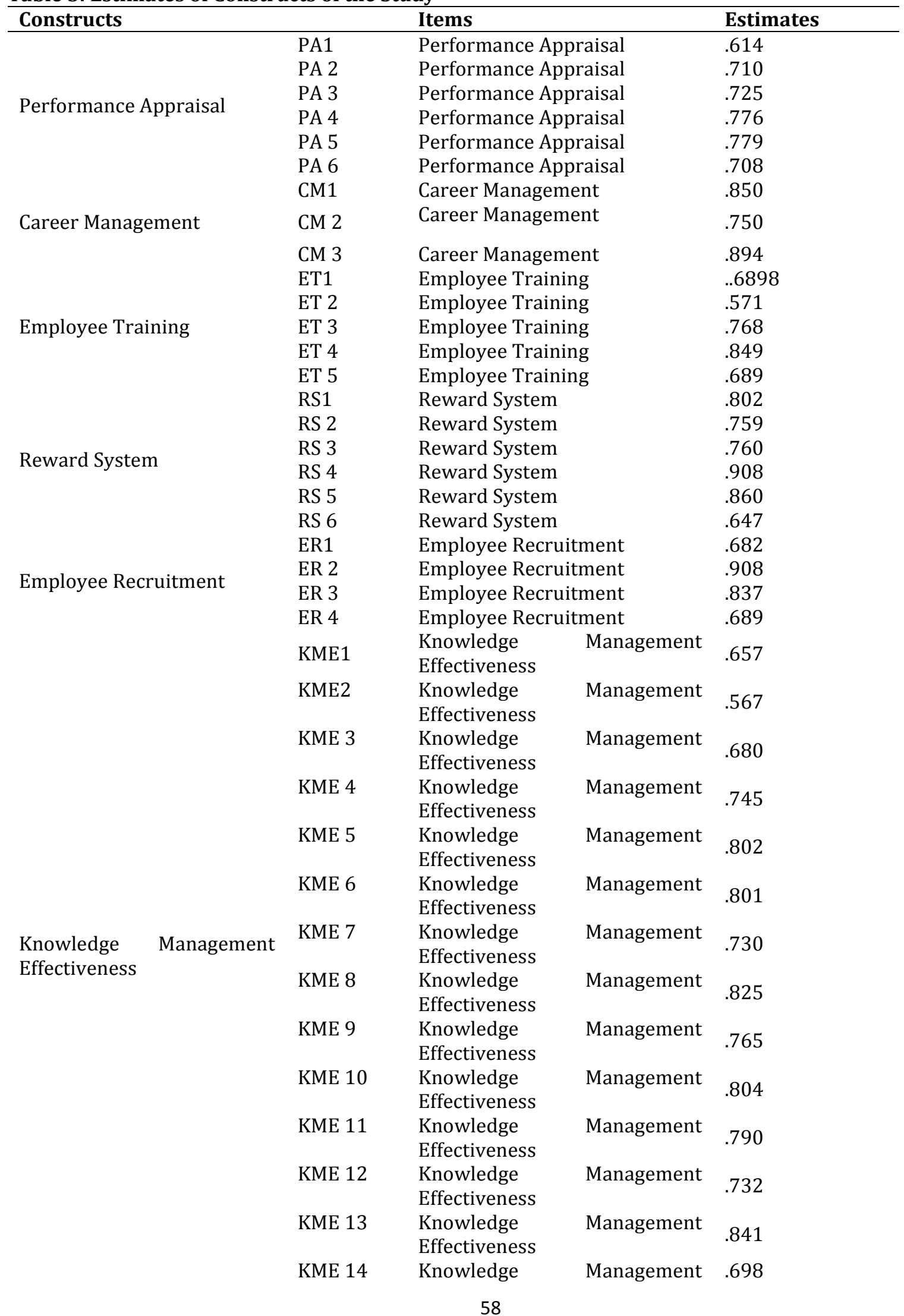




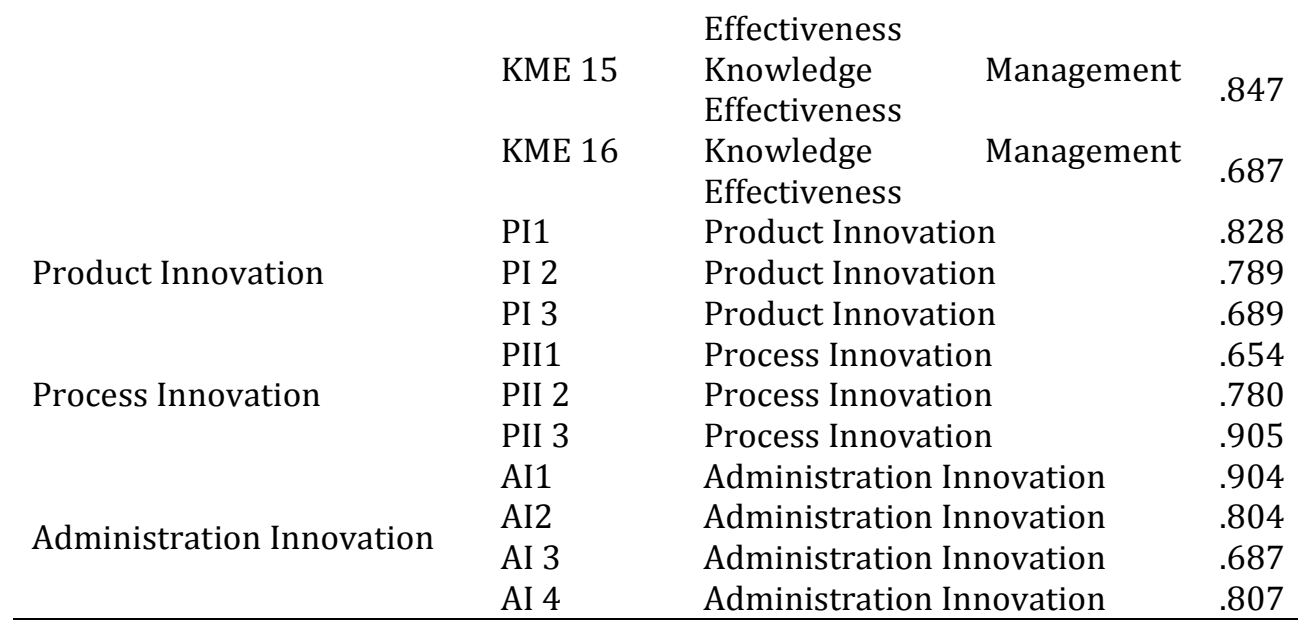

Through confirmatory factor approach of assessing measurement model, the maximum likelihood (ML) estimation method was employed (Hooper et al., 2008; Hair et al., 2006).

\section{Results}

Analysis of Demographics: The sample of target respondents for this study was 290 who were rendering their services in different departments at different sites in the telecommunication sector of Pakistan. Table 4 demonstrates the composition of all the respondents of the study. According to the table 4, there were 290 respondents, 203 were male, 87 were female, and sample consists of $30 \%$ of female and $70 \%$ of male employees. In distribution of age the table shows that most of employees were in age bracket of 31-40, 42.8 $\%$ of employees and $15.9 \%$ were in age bracket of $21-30$. In the age bracket of $41-50$, there were $41.4 \%$ respondents. Married and unmarried both employees were considered into this sample. Married and unmarried status of employees is shown in this table. The table demonstrates that $56.9 \%$ employees were married and $43.1 \%$ were unmarried. Respondents were requested to

Table 4: Frequency Distribution of Demographic Profile of the Respondents

\begin{tabular}{llll}
\hline Demographic & Category & Frequency & Percent \\
\hline \multirow{2}{*}{ Gender } & Male & 203 & 70.0 \\
& Female & 87 & 30.0 \\
Age & $21-30$ & 46 & 15.9 \\
& $31-40$ & 124 & 42.8 \\
Marital Status & $41-50$ & 120 & 41.4 \\
& Married & 165 & 56.9 \\
\multirow{2}{*}{ Qualification } & Unmarried & 125 & 43.1 \\
& Graduate & 141 & 48.6 \\
& Master & 89 & 30.7 \\
Service Period & MS/M. Phil & 55 & 19.0 \\
& PhD & 5 & 1.7 \\
& $1-2$ & 64 & 22.1 \\
Total & $3-5$ & 51 & 17.6 \\
& $6-10$ & 76 & 26.2 \\
& More than ten years & 99 & 34.1 \\
\end{tabular}

Note. $\mathrm{N}=290$.

Indicate their highest educational qualification. Qualification data shows that that most respondents are graduated from the selected sample. Data shows that $48.6 \%$ employees were Graduated, $30.7 \%$ were Master, 19\% were MS/M, Phil and 1.7\% were Ph. Ds. Qualification data shows that mostly respondents had 
more than ten year experience in the existent organization where there are working. Therefore, the percentage is $34.5 \%$ had more than ten years experience in current organization and $26.2 \%$ had 6 to 10 years experience in current organization.

Hypothesis Testing: A regression analysis was conducted to test hypothesis $\mathrm{H} 1$ and sub - hypotheses $\mathrm{H} 1 \mathrm{a}$, $\mathrm{H} 1 \mathrm{~b}$ and H1c. Six variables of human resource management practices (employee performance appraisal, employee career management, employee training, reward system, recruitment, and employee recognition) were penetrated. Regression analysis among human resource management practices and organizational innovation outcomes are publicized in Table 5.

Table 5: Results of Regression Test Showing the Impact of HR Practices on Organizational Innovation

\begin{tabular}{llll}
\hline Predictors & $\begin{array}{l}\text { Product Innovation } \\
\text { Std. } \boldsymbol{\beta}\end{array}$ & $\begin{array}{l}\text { Process Innovation } \\
\text { Std. } \boldsymbol{B}\end{array}$ & $\begin{array}{l}\text { Administrative } \\
\text { Innovation } \\
\text { Std. } \boldsymbol{\beta}\end{array}$ \\
\hline HRM Practices: & & & \\
Performance appraisal & 0.11 & 0.07 & $0.21^{*}$ \\
Career management & 0.11 & 0.18 & 0.15 \\
Training & $0.36^{* *}$ & $0.29^{* *}$ & $0.30^{* *}$ \\
Reward system & 0.09 & 0.03 & 0.03 \\
Recruitment & 0.04 & $0.24^{* *}$ & 0.07 \\
Employee Recognition & $0.34^{* *}$ & $0.27^{* *}$ & $0.28^{* *}$ \\
$\mathrm{R}^{2}$ & 0.20 & 0.19 & 0.31 \\
Adjusted R & 0.16 & 0.15 & 0.28 \\
$\mathrm{R}^{2}$ & 0.18 & 0.18 & 0.30 \\
F-value $\triangle$ & $5.72^{* *}$ & $5.32^{* *}$ & $10.37^{* *}$ \\
F-value $\triangle$ & $7.12^{* *}$ & $6.93^{* *}$ & $14.26^{* *}$ \\
\hline
\end{tabular}

Note: ${ }^{* *} \mathrm{p}<0.01,{ }^{*} \mathrm{p}<0.05$

As shown in table, the $\mathrm{R}^{2}$ of products innovation is $0.20 \%$ represents that the six elements of human resource management practices donated $20.0 \%$ to the variance in products innovation. Conversely, the $\mathrm{R}^{2}$ of process innovation is $0.19 \%$ showing that the six dimensions of human resource management practices donated $19.0 \%$ to the variance in processes innovation. The $\mathrm{R}^{2}$ of administrative innovation shows a sudden boost to $0.31 \%$ viewing that the six dimensions of human resource management practices donated $31.0 \%$ to the variance in administrative innovation. The $\mathrm{F}$ - change of products innovation (7.12\%), processes innovation $(6.93 \%)$ as well as administrative innovation $(14.26)$, was significant $(p<0.01)$. Out of six human resource management practices, only training and employee recognition were observed to be positively and significantly associated to organizational innovation. The result further reveals that training influences product innovation as $(\beta=0.36, \mathrm{p}<0.01)$, process innovation $(\beta=0.29, \mathrm{p}<0.01)$ and administrative innovation $(B=0.30, \mathrm{p}<0.01)$. The employee recognition has influence on products innovation as $(\beta=0.34, p<0.01)$, processes innovation $(\beta=0.27, p<0.01)$ and administrative innovation $(ß=0.28, p<0.01)$. Performance appraisal was also demonstrated to be positively and significantly linked to administrative innovation $(\beta=0.21, \mathrm{p}<0.05)$. Career management, reward system, recruitment and employee recognition did not depict any association with products innovations, processes innovations and administrational innovations. The results showed partially support for hypothesis H1a, H1b and H1c.

Baron and Kenny (1986) and Kenny (2003) followed the four-step process suggested to ensure the mediating role of knowledge management effectiveness as a hypothesis H2. Previous and initial outcomes of hierarchical regression on the relationship among human resource management practices and firm innovations (products innovation, processes innovation and administrative innovation) (Table 5). Thus further analysis on the relationship among human resource management practices and knowledge management effectiveness $(B=0.34, p<0.01$ ) revealed that employee performance appraisal and employee training cover the mediation effect. Table 5, 6 and 7 indicated the results of the mediation effects 
of knowledge management effectiveness on the association among human resource management practices and firm innovations (products innovations, processes innovations and administrational innovations).

Table 6: Mediation Analysis of Knowledge Management Effectiveness on the Association among HR Practices and Products Innovation

\begin{tabular}{|c|c|c|c|}
\hline \multirow[b]{2}{*}{ Predictors } & \multicolumn{3}{|l|}{ Criterion Variables } \\
\hline & $\begin{array}{l}\text { Product Innovation } \\
\text { (Without KME) } \\
\text { Std. B }\end{array}$ & $\begin{array}{l}\text { Knowledge } \\
\text { Management } \\
\text { Effectiveness (KME) } \\
\text { Std. B } \\
\end{array}$ & $\begin{array}{ll}\text { Product } & \text { Innovation } \\
\text { (With KME) } & \\
\text { Std. } ß & \end{array}$ \\
\hline Training & $0.39^{* *}$ & $0.36^{* *}$ & $0.23^{*}$ \\
\hline Recognition & $0.37^{* *}$ & $0.34^{* *}$ & $0.21^{*}$ \\
\hline KME & - & - & $0.34^{* *}$ \\
\hline $\mathrm{R}^{2}$ & 0.76 & 0.20 & 0.25 \\
\hline Adjusted $\mathrm{R}^{2}$ & 0.75 & 0.16 & 0.21 \\
\hline $\mathrm{R}^{2} \quad \Delta$ & 0.76 & 0.18 & 0.23 \\
\hline F-value & $70.32^{* *}$ & $5.72^{* *}$ & $6.68^{* *}$ \\
\hline F-val $\triangle \mathrm{e}$ & $98.21^{* *}$ & $7.12^{* *}$ & $8.12^{* *}$ \\
\hline
\end{tabular}

Note: ${ }^{* *} p<0.01,{ }^{*} p<0.05$. KME indicates knowledge management effectiveness.

According to Table 6, the effect of employee training and employee recognition on products innovations were observed important without knowledge management effectiveness $(B=0.36, p<0.01 ; \beta=0.34, p<$ 0.01 ) and with knowledge management effectiveness $(B=0.23, p<0.01 ; \beta=0.21, p<0.01)$. From other side the beta value decreased in the presence of knowledge management effectiveness; result designated the partial mediation. Employee training and employee recognition have indirect influence on products innovation through knowledge management effectiveness. So as a result, sub-hypothesis H2a is accepted.

Table 7: Mediation Analysis of Knowledge Management Effectiveness on the Relationship between HR Practices and Process Innovation

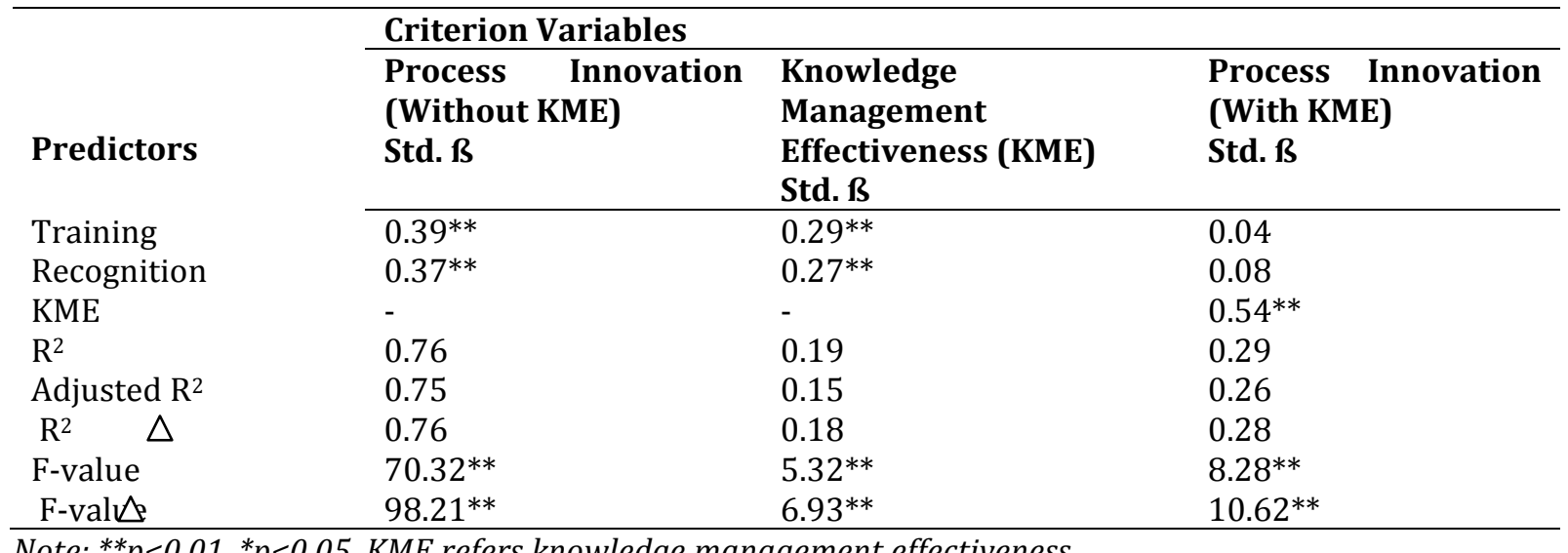

Note: ${ }^{* *} p<0.01,{ }^{*} p<0.05$. KME refers knowledge management effectiveness.

Table 7, the results of mediation effect of knowledge management effectiveness on the association among human resource management practices and process innovation are shown. Employee training have impact on processes innovation $(B=0.29, p<0.01)$ turned out to be insignificant in the presence of knowledge management effectiveness $(\beta=0.04, p>0.05)$, the impact of employee recognition turned out to be significant $(\beta=0.27, p<0.01)$ and insignificant in the presence of knowledge management effectiveness ( $B$ $=0.08, p<0.05$ ), so entailing high mediation. It may be inferred that training and employee recognition have indirect influence on processes innovations through knowledge management effectiveness. Therefore, the hypothesis $\mathrm{H} 2 \mathrm{~b}$ is supported. 
Table 8: Mediation Analysis of Knowledge Management effectiveness on the Association between HRM Practices and Administration Innovation

\begin{tabular}{llll}
\hline & Criterion Variables & \\
\cline { 2 - 4 } & $\begin{array}{l}\text { Knowledge Management } \\
\text { Effectiveness } \\
\text { (KME) } \\
\text { Std. B }\end{array}$ & $\begin{array}{l}\text { Administrative } \\
\text { Innovation } \\
\text { (Without KME) } \\
\text { Std. B }\end{array}$ & $\begin{array}{l}\text { Administrative } \\
\text { Innovation } \\
\text { (With KME) } \\
\text { Std. B }\end{array}$ \\
\hline Performance appraisal & $0.16^{* *}$ & $0.21^{*}$ & 0.12 \\
Training & $0.39^{* *}$ & $0.30^{* *}$ & 0.10 \\
Recognition & $0.37^{* *}$ & $0.28^{* *}$ & 0.12 \\
KME & - & - & $0.52^{* *}$ \\
$\mathrm{R}^{2}$ & 0.76 & 0.31 & 0.43 \\
Adjusted R $\mathrm{R}^{2}$ & 0.75 & 0.28 & 0.40 \\
$\mathrm{R}^{2} \Delta$ & 0.76 & 0.30 & 0.43 \\
F-value & $70.32^{* *}$ & $10.37^{* *}$ & $15.29^{* *}$ \\
F-value $\triangle$ & $98.21^{* *}$ & $14.26^{* *}$ & $20.14^{* *}$ \\
\hline
\end{tabular}

Note: ${ }^{* *} p<0.01,{ }^{*} p<0.05$. KME refers to knowledge management effectiveness.

As shown in Table 8, the performance appraisal influence $(B=0.21, p<0.01)$ was insignificant in the presence of knowledge management effectiveness $(\beta=0.12, p>0.05)$, thus including high mediation. Similarly, the impact of employee training $(B=0.30, p>0.01)$ on administrative innovation was insignificant in the presence of knowledge management effectiveness $(\beta=0.10, p>0.05)$. Although, the impact of employee recognition $(\beta=0.28, p>0.01)$ on administrational innovation is insignificant $(\beta=$ $0.12, \mathrm{p}>0.05$ ) in the presence of knowledge management effectiveness and shows high mediation. The related significant of results showed that performance appraisal; employee training and employee recognition have indirect impact on administrational innovations through knowledge management effectiveness. So hypotheses H2c are accepted and overall hypothesis 2 is partially accepted.

Discussion: The purpose of this research was to examine the indirect relationship among organizational innovation and human resource management practices and direct association among organizational innovation and human resource management practices via knowledge management effectiveness. Arithmetical consequences attained in the research demonstrated that HM practices have a significant impact on firm innovation. The mediation effect of effective knowledge management on association among firm innovation and human resource management practices. However, mainly two of six human resource practices that are employee training and employee recognition were established to have mutually indirect and direct effect on all the facets of firm innovation. This consequence exposed that when organization has higher execution stage of employee training, it enhances advance growth of individual's obligatory expertise and their motivation to learn. Individuals are capable to create latest ideas and innovative dreams. These innovative ideas and dreams are helpful for firm innovational process. Consequently, challenges taken for development of knowledge management effectiveness in the telecommunication sector of Pakistan are helpful in enhancing the firm innovational process. This research outcome elaborated many proposes to mix of (product and services) and especially to services sectors of Pakistan. Therefore, these outcomes helped the management for deciding and implementing the required training and development programs. Individuals accept the training programs as projected to employ the knowledge obtained on the work. In other words, the high level of execution of training and employee recognition, the supplementary transmit of information and knowledge that will enhance organizational knowledge and encourage innovative thoughts, guiding to products innovation, processes innovation and administrative innovation (Anvari \& Amin, 2011; Delise et al., 2010; Ullah \& Rehman, 2015).

Employee training increase declarative knowledge of individual's employees concerning their entity or group abilities, considering them excel and ace up their relationship and trend of helping in achieving the diverse responsibilities and attaining the challenge (Ullah \& Yasmin, 2013). Therefore, sharing of knowledge may be pointed out between employees via creating the learning and accommodating 
environment in the organization. It is important in the shape of construction of global and dedicated work deeds between them. So collectively, employees share their capabilities to include their ideas and rising everyday jobs requirements. Performance appraisal conversely was established to have twice effects like indirect and direct on administrational innovations, although products innovation and processes received no indirect or direct effect. Administrative innovation generally made within a shorter period as administrative process and system may be accustomed according to the desires of the company because, it is one of the promising clarifications. Normally feedback from performance appraisal actions, generally performed at least one time yearly may facilitate the firm for further improvement of administrative practices of innovation. Conversely, products innovation and processes innovation acquire a long-term period and possibility for many years to give up outcomes due to technicality restraints, which come on front during actualization of processes and products. Therefore, there is no impact on products innovation and processes innovational process according to feedback of performance appraisal. It showed that the individual's motivational levels towards their everyday activities of jobs based on the fair and better execution system of performance appraisal. Positive motivation of individual employees facilitates and enhances the innovative ideas and thinking in order to enhance administrative innovation (Marescaux, Winnie \& Sels, 2010; Tan \& Nasurdin, 2011; Prasetya \& Kato, 2011).

Amazingly, a number of human resource practices (reward system, selection, employee career management and recruitment) were examined to be not related to firm innovational system (processes innovations, products innovations and administrational innovation). Divergent to anticipation, both recruitment and compensation process were significantly associated to products innovations and processes innovations. According to Chew (2000), telecom firms have diverse patterns while recruiting individuals. Usually, some organizations are hostile and have obvious selection criterion and their recruitment assessment depend on joint effort between human resource managers and directors. In disparity, some organizations fundamentally do not have obvious criterion for recruitment, and the recruitment assessments depend greatly on manager or director's personal opinion. In attempt to achieve competitive benefits, the firms have under strain to decrease operational and administrative expenses. According to Schuler (1989), organizations are more probable to exercise reduce overhead, strict control and trail economics of scale. Moreover, tight control can guide to most of the organizations very cost-sensitive. Therefore, regarding rewards might have accounted for the no significant association between all the three facets of firm innovations (products innovations, processes innovations and administrational innovations) by Tan and Nasurdin (2010).

The individuals learn best, when employee received the respect, and this respect is right of every employee in the organization. If we look at the quality of experience that employees undergo during their education, we will arrive at the conclusion that is filled with feelings of fear, insecurity, rejection, embarrassment, humiliation and guilt (Tourangeau \& Cranley, 2006). Recognizing people is to accept and acknowledge for what they are. People may not be recognized conditionally on the basis of gender, race etc because they must be recognized wholly on the behalf of human beings. Individuals show phenomenal development, when they are accepted along with their individual learning styles and pace. Employees must be recognized for what they do instead of what they not done (Hausknecht, Rodda \& Howard, 2009).

\section{Conclusion}

It is clear from the results that human resource practices have a considerable constructive influence on the innovation. The results also showed mediation effect of KME on association among organizational innovation and human resource practices. However, it was found that only training had direct as well as indirect impact on the constructs of organizational innovation. Performance appraisal has mutually direct as well as indirect impact on administrative innovation. However, it had no impact on products innovation and processes innovation. Conversely, processes innovation and products innovation acquire a long-term period, possibly numerous years to give up outcomes because of technological restraints confronted in products and processes realization. Therefore, the response from performance appraisal movement cannot have an impact on processes and products innovation. It denotes the high intensity of execution of reasonable performance appraisal, the high intensity of individuals' inspiration to the everyday jobs of 
individuals. Elevated inspiration will facilitate to enhance individuals' motivation to produce innovative thinking in order to enhance administrative innovation. So reward system, employee career management, recruitment and selection were noted not to be related to firm innovation.

Recommendations: This research renders a number of recommendations. Each and every employee should be responsive with significance job behavior and innovative thoughts among any business group and if their recognition of this wisdom does not come up to dead heart and deaf ears then stage of their skill and ability can be enhanced through appropriate management reaction by recognition. The top management of the organization should provide the atmosphere of knowledge, collaboration among employees, dedicated administration, suitable satisfying employee training requirements, job security, admiration on admirable performance, proficient and successful planning for their professional activities to its workforce for attaining the objectives of the organization. Better and desired career planning has impact on better performance of employees. Views and discussion of management and incorporation as a source for improvement of employee attitude and behavior towards achieving the organizational goals. It is recommended that human resource managers should recognize the significance of Career planning particularly for employees' job improvement for achieving their tasks, which were settled by the management of the organization. Recognize and accept the employee positive efforts for enhancing the motivational level. The individuals learn best when they are respected and this respect is every individuals' right. People may not be recognized conditionally on the basis of gender, race, culture, behavior, attitude etc. they must be recognized wholly because they are human beings and the great and important assets of the organization. Employees must be recognized for what they do instead of what they not done because it is a tip to improve the employee performance through positive way.

Research Limitations and Direction for Future Research: The present research has several limitations. The firs limitation is about data collection because the data was cross-sectional that restrains our skill to build causal assumptions. Particularly, definite human resource practices for example career management, organizational reward system, employee selection and recruitment might not have instant impact on innovation. Therefore, a very famous and reasonable approach would be to perform a longitudinal study and another limitation of study is specific targeted area for research. The present research is restricted to telecom sector sited in Rawalpindi and Islamabad, Pakistan. The results of this study cannot be generalized for other samples on other fields or places, so further research should be replicated with another sample from different areas within the same industry that will enhance and advance the generalization of the outcomes. Lastly, this study was restricted only in telecom sector of Pakistan. Future study should be extended to other services providers sectors for example health, education and banking sector.

\section{References}

AL-Hakim, L. A. \& Hassan, S. (2011). The Role of Middle Managers in Knowledge. International Journal of Innovation, Management and Technology, 2(1), 86-94.

Alshekaili, S. A. R. \& Boerhannoeddin, A. (2011). Human Capital Approach towards Enhancing Innovation Performance in Omani Industrial Firms: The role of Knowledge Management. Progress in Business Innovation and Technology Management, 001, 23-33.

Amidon, D. M. (2006). Innovation strategy for the knowledge economy: the ken awakening. New York: Reed Educational \& Professional Publishing Ltd., 213-226.

Anvari, R. \& Amin, S. M. (2011). Strategic training practices and turnover intention: The mediating role of organizational commitment. International Journal Business and Management Studies, 3(2), 293-305.

Baron, R. M. \& Kenny, D. A. (1986), .The moderator-mediator variable distinction in social psychological research: Conceptual, strategic and statistical considerations. Journal of Personality and Social Psychology, 51(6), 1173-1182.

Chen, C. J. \& Huang, J. W. (2009) .Strategic human resource practices and innovation performance - the mediating role of knowledge management capacity. Journal of Business Research, 62(1), 104-114.

Chew, C. H. (2000). Organizational cultural characteristics and innovation: A perspective from electrical and electronics industry in Penang. Unpublished M.B.A dissertation, Universiti Sains Malaysia, Penang, Malaysia. 
Chuang, L. M. (2005). An empirical study of the construction of measuring model for organizational innovation in Taiwanese high-tech enterprises. The Journal of American Academy of Business, 9(2), 299-304.

Cooper, C. L. (1998). The changing nature of work [1]. Community, Work \& Family, 1(3), 313-317.

Damanpour, F. \& Gopalakrishnan, S. (2001), .The dynamics of the product and process innovations in organizations. Journal of Management Studies, 38(1), 45-65.

Damanpour, F., Szabat, K. A. \& Evan, W. M. (1989), .The relationship between types of innovation and organizational performance. Journal of Management Studies, 26(6), 587-601.

Darroch, J. \& McNaughton, R. (2002), .Examining the link between knowledge management practice and types of innovation. Journal of Intellectual Capital, 3(3), 210-222.

Delery, J. E. \& Doty, D. H. (1996), .Modes of theorizing in strategic human resource management: Tests of universalistic, contingency, and configurational performance predictions. Academy of Management Journal, 39(4), 802-835.

Delise L. A., Gorman, C. A., Brooks, A. M., Rentsch J. R. \& Steele-Johnson, D. (2010). The Effects of Team Training on Team Outcomes: A Meta-Analysis. Performance Improvement Quarterly, 22(4), 53-80.

Feng-Chuan Liu, Cheng, k. l, Chao, H. M. \& Tseng, H. M. (2012). Team Innovation Climate and Knowledge Sharing among Healthcare Mangers: Mediation effects of Altuistic Intentions. Chang Gung Med J., 35(5), 408-419.

Gold, A. H., Malhortra, A. \& Segras, A. H. (2001), .Knowledge management: An organizational capabilities perspective. Journal of Management Information Systems, 18(1), 185-214.

Gupta, A. \& Singhal, A. (1993), .Managing human resources for innovation and creativity. Research Technology Management, 36(3), 8-41.

Hair, J. F., Black, Jr. W. C., Babin, B. J., Anderson, R. E. \& Tatham, R. L. (2006). Multivariate Data Analysis, $6^{\text {th, }}$ PEARSON Prentice Hall, USA.

Harter, J. K., Schmidt, F. L. \& Hayes, T. L. (2002), .Business-Unit-Level relationship between employee satisfaction, employee engagement, and business outcomes: A meta-analysis. Journal of Applied Psychology, 87(2), 268-279.

Hausknecht, J. P., Rodda, J. \& Howard, M. J. (2009). Targeted employee retention: Performance based and jobrelated differences in reported reasons for staying. Human Resource Management, 48(2), 269-288.

Hislop, D. (2003). Linking human resource management and knowledge management via commitment: A review and research agenda. Employee relations, 25(2), 182-202.

Hooper, D., Coughlin, J. \& Mullen, M. R. (2008). Structural Equation Modeling: Guidelines for Determining Model Fit. Elect. J. Bus. Res. Methods, 6(1), 53 - 60.

Huselid, M. A. (1995), .The impact of human resource management practices on turnover, productivity and corporate financial performance. Academy of Management Journal, 38(3), 635-672.

Ismail, M. (2005). Pharmacokinetics of cefepime administered by iv and im routes to ewes. Journal of veterinary pharmacology and therapeutics, 28(6), 499-503.

Jolibert, A. \& Jourdan, P. (2006). Marketing Research - Méthodes De Recherche Et D'études En Marketing. Paris: Dunod.

Jiménez-Jiménez, J. \& Sanz-Valle, R. (2005). Innovation and human resource management fit: An empirical study. International Journal of Manpower, 26(4), 364-381.

Kenny, D. A. (2003). Mediation. Available from http://davidkeny.net $/ \mathrm{cm} / \mathrm{mediate} / \mathrm{htm}$

Kraimer. (2011). Antecedents and outcomes of organizational support for development: The critical role of career opportunities. Journal of Applied Psychology, 96(3), 485-500.

Laursen, K. \& Foss, N. J. (2003). New human resource management practices, complementarities and the impact on innovation performance. Cambridge Journal of economics, 27(2), 243-263.

Ling, T. C. \& Nasurdin, A. Z. (2010). The influence of knowledge management effectiveness on administrative innovation among Malaysian manufacturing firms. Asian Academy of Management Journal, 15(1), 6377.

Marescaux, E., Winnie, S. D. \& Sels, L. (2010). HRM practices and work outcomes: The role of basic need satisfaction.

Mesmer-Magnus, J. R. \& DeChurch, L. A. (2009). Information sharing and team performance: A meta-analysis. Journal of Applied Psychology, 94, 535-546. 
Miller, D. \& Friesen, P. H. (1982), .Innovation in conservative and entrepreneurial firms: Two models of strategic momentum. Strategic Management Journal, 3(1), 1-25.

Morrow, P. C. \& McElroy, J. C. (2003), .Work commitment conceptual and methodological developments for the management of human resources. Human Resource Management Review, 11(3), 177-180.

Moynihan, L. M., Gardner, T. M., Park, H. J. \& Wright, P. M. (2001). HR Practices and Customer Satisfaction: The Mediating Link of Commitment. (CAHRS Working Paper 01-14), Ithaca, NY: Cornell University, School of Industrial and Labor Relations, Center for Advanced Human Resource Studies. Available from http://digitalcommons.ilr.cornell.edu/cahrswp/77.

Navarro, A., Acedo, F. J., Robson, M., Ruzo, E. \& Losada, F. (2010). Antecedents and Consequences of Firm's Export Commitment: An Emperical Study. Journal of International Marketing , 18(3), 41-61.

Paauwe, J. \& Boselie, P. (2005), .HRM and performance: What's next? Human Resource Management Journal, $15(4), 68-83$.

Popadiuk, S. \& Choo, C. W. (2006). Innovation and knowledge creation: How are these concepts related? International Journal of Information Management, 26(4), 302-312.

Prasetya, A. \& Kato, M. (2011). The Effect of Financial and Non-Financial Compensation to Employee Performance. The 2nd International Research Symposium in Service Management Yogyakarta, Indonesia, 26-30.

Rogg, K. L., Schmidt, D. B., Shull, C. \& Schmitt, N. (2001). Human resource practices, organizational climate, and customer satisfaction. Journal of management, 27(4), 431-449.

Schuler, R. S. (1989). Strategic human resource management and industrial relations. Human Relations, 42(2), 157-184.

Sekaran, U. (2006). Research methods for business: A skill building approach. John Wiley \& Sons.

Singh, S. K., Hawkins, C., Clarke, I. D., Squire, J. A., Bayani, J., Hide, T. \& Dirks, P. B. (2004). Identification of human brain tumour initiating cells. Nature, 432(7015), 396-401.

Shipton, H., Fay, D., West, M., Patterson, M. \& Birdi, K. (2005), .Managing people to promote innovation. Creativity and Innovative Management, 14(2), 118-128.

Tan, C. L. \& Nasurdin, A. M. (2010). Human Resource Management Practices and Organizational Innovation: An Emperical Study in Malaysia. The Journal of Applied Business Research, 26(4), 105-116.

Tan, C. L. \& Nasurdin, A. M. (2011). Human Resource Management Practices and Organizational Innovation: Assessing the Mediating Role of Knowledge Management Effectiveness. Electronic Journal of Knowledge Management, 9(2), 155-167.

Tourangeau, A. E., \& Gravly, L. A. (2006). Nurse Intention to remain employed: Understanding and strengthening determinants. Journal of advance nursing, 55(6), 497-509

Tung, L. L. (2004), .Knowledge management: An exploratory study on manufacturing companies in Penang. Unpublished M.B.A. dissertation, Olympia College Penang, Nottingham Trent University, United Kingdom.

Ullah, I. \& Rehman, K. U. (2015). Effect of Gender of Leader (Transformational/ Transactional), Satisfaction with the Leader on Employee Turnover Intention. Global Advanced Research Journal of Educational Research and Review, 4(6), 097-104.

Ullah, I. \& Yasmin, R. (2013). The Influence of Human Resource Practices on Internal Customer Satisfaction and Organizational Effectiveness. Journal of Internet Banking and Commerce, 18(2). 1-28.

Ullah, I., Usman, M., Niazi, A. S., Farooq, M., Afzal, W. \& Khan, M. A. (2012). Being Dissimilar: Religious Dissimilarity, Gender Dissimilarity, Value Dissimilarity and Job Satisfaction. Information Management and Business Review , 4(2), 56-63.

Usman, M., Ullah, I., Kayani, M. B., Haroon, F. \& Khan, M. A. (2012). The Impact of Marketing Mix and Market Orientation on Export Performance. Journal of Economics and Behavioral Studies, 4(1), 66-71.

Wang, C. L., Tomas, M. T., Ketchen, D. J. \& Ahmed, P.K. (2008). Knowledge management orientation, Market orientation, and firm performance: an integration and empirical examination. J. Strateg. Martet, $17(2), 99-122$.

Wang, S. \& Noe, R. A. (2010). Knowledge sharing: A review and directions for future research. Human Resource Management Review, 20(2), 115-131.

Wang, S., Noe, R. A. \& Wang, Z. M. (2014). Motivating knowledge sharing in knowledge management systems a quasi-field experiment. Journal of Management, 40(4), 978-1009. 
Wan-Jusoh, W. J. (2000). Determining key success factors in new product development: Evidence from manufacturing companies in Malaysia. Journal of International Business and Entrepreneurship, 8(1), 21-40.

Weisberg, R. W. (2006). Creativity: Understanding innovation in problem solving, science, invention, and the arts. John Wiley \& Sons.

Wright, P. M. \& McMahan, G. C. (1992), .Theoretical perspectives for strategic human resource management. Journal of Management, 18(2), 295-320.

Yazhou, W. \& Jian, L. (2013). An empirical research on knowledge management orientation and organizational performance: the mediating role of organizational innovation. African Journal of Business Management , 7(8), 604-612.

Zoghi, C., Mohr, R. \& Meyer, P. (2010). Workplace organization and innovation. Canadian Journal of Economics, 43(2), 622-639. 